\title{
HRM Practices and its Impact on Employee Performance: A Study on the Cement Industry in Bangladesh
}

\author{
Mst. Momena Akhter ${ }^{1}$, Md. Nur-E-Alam Siddique ${ }^{2}$, Md. Asraful Alam ${ }^{3}$
}

${ }^{1}$ Lecturer, Faculty of Business, ASA University Bangladesh

${ }^{2}$ Senior Lecturer, Faculty of Business, ASA University Bangladesh

${ }^{3}$ Senior Administrative Officer, ASA University Bangladesh

\begin{abstract}
In present situation, companies can gain strong competitive advantage through applying effective and efficient human resource practices. If the human resources are managed properly, they can contribute to the success for the company. The effective management of human resource is possible through the implementation of sound HRM practices. . The main objective of this research is studying the impact of HRM practices on employee performance in the context of cement industry in Bangladesh. For this purpose the researchers have tried to investigate impact of the various components of HRM practices on employee performance of a sample of 160 employees from seven cement companies listed in the Dhaka Stock Exchange. The data were analyzed by a regression analysis to determine the impact of HRM practices on employee performance. The result shows that training \& development and opportunity for career development have a significant positive impact on employee performances. On the other hand, Performance appraisal, Compensation \& Benefits, and Leadership Practices have a positive impact on employee performance but the impact is not significant in the context of cement industry in Bangladesh. Moreover, work life balance has a negative impact on employee's performance. Furthermore, efficient management of human resources can increase the performance of the employees of the cement companies in Bangladesh.
\end{abstract}

Key-Words: Employees performance, HRM Practices, Performance Appraisal, work life balance, Training and Development, leadership practices, career development etc.

JEL Classification Code: M12; J53

\section{INTRODUCTION}

Human resource of the organization is the source of achieving competitive advantage because of its competency to convert the other resources (money, machine, methods \& material) into output (product/service). They are one of the most important factors providing flexibility and adaptability to organization (Khatri, 1999). Further, Rundle (1997) 
said that one needs to bear in mind that people (managers), not the firm, is the adaptive mechanism in determining how the firm will respond to the competitive environment. The competitors can imitate other resources like technology, capital, raw material but it is quite impossible to imitate the human resources. All these factors made them a unique resource and necessitate their effective management.

Impact of human resource management practices on employee performance has been a widely researched area for years. Several Scholars have noted that managing people is more difficult than managing technology or capital (Barney, 1991; Lado and Wilson, 1994). However those firms that have learnt how to manage their human resources well would have an edge over others for a long time to come because acquiring and deploying human resources effectively is cumbersome and takes much longer time (Wright et al.,2003).

Cement industry of Bangladesh is closely associated with the building and construction activities wherein it is used as bonding agent to unite particles. In Bangladesh out of the total cement supply to the market around $20 \%$ is consumed by the public sector and the rest is consumed by the private sector. In a recent statistics of demand and supply position of cement in our country, it was reported that during the year 2010 the demand of cement was around 12.5 million MT per annum whereas the supply of cement was almost 1.5 times higher than its demand. However it is predicted that the demand of cement will likely to be increased within the next few years as some big national projects are under active consideration of the government. This would create a good demand for cement in the coming years creating more opportunities for consumption of products of this sector and human resource would be the corner stone for the sustainable growth of the companies through satisfying their goals and objectives. Therefore, the management of the companies should view their employees as assets for their steady and sustained development and maintaining of the competitive advantage in business. The companies should maintained a uniform and effective human resource management policies and practices in order to motivate and develop their employees and executives and ensure their optimum utilization in achieving the corporate goals.

Results of studies, from developed to developing countries have been time and again showing that HR practices have significant impact on organizational performance. (Delaney \& Huselid, 1996; Katou \& Budhwar, 2007; Sing, 2004; Tzafrir, 2006). But unfortunately, very insufficient numbers of studies have been conducted in this area in the context of Bangladesh and other developing countries. There is no research on the human resource practice in the cement industry of Bangladesh.

Hence, it becomes pertinent to measure the impact of $\mathrm{HR}$ practices on employee performance of the cement industry in Bangladesh and to augment the contemporary knowledge base of HR practices of the cement industry, this study has been undertaken. The remainder of the paper is organized as follows. Section two reviews the literature on impact of human resource management practices and policies on employee and organizational performance followed by the objectives and conceptual framework of the study. The next section discusses the methodology used in the study and section six discusses the empirical findings and section five concludes.

\section{REVIEW OF RELATED LITERATURE}

In a rapidly changing market worldwide, regulators, managers, and investors are concerned about how efficiently transform their expensive inputs into various products and services. This transformation of input into output depends on the efficient \& effective 
use of human resources. As the study focuses on the impact of HRM practices on employee's performance, the researchers have reviewed the important studies available on the impact of HRM practices on organizational performance as well as on employee's performance. The review of these studies is as follows:

Birdi et al, (2008) examined the impact of human resource and operational management practices on company productivity and concluded that performance benefits from employee empowerment and extensive training. In contrast, none of the operational practices were directly related to productivity nor did they interact with other practices in ways fully consistent with the notions of integrated manufacturing or lean production.

Khan, (2010) evaluated the effects of human resource management practices on organizational performance in Oil and Gas Industry in Pakistan and found a significant association of HRM practices with organizational performance.

In another study, Shahzad et al., (2008) conducted a study among university teachers in Pakistan. The results of the study indicate a positive relationship between compensation and, promotion practices and employee perceived performance while performance evaluations practices are not significantly correlated with perceived employee performance.

Collins et al., (2005) investigated the small businesses and found that effective HR practices impact employee outcomes significantly. Guest, (2002) has argued that the Impact of HRM on performance depends upon worker's response to HRM practices, so the impact will move in direction of the perception of HRM practices by the employee. If the perception is positive the impact will be positive and if the perception is negative the impact will be negative. Wright et al., (2003) were of the view that an employee will exert discretionary effort if proper Performance management system is in place and is supported by compensation system linked with the performance management system.

Marwat et al., (2009) explored contribution of human resource management practices in telecom sector on perceived employee performance in telecom sector in Pakistan. Results highlighted that all the tested variables are positively correlated but correlation of compensation and training are highest respectively.

In a recent study, Baloch et al., (2010) measured the impact of three HR practices which are compensation practices, promotion practices and performance evaluation practices on perceived employee performance. The results of correlation indicated a significant relationship between compensation practices and perceived employee performance, promotion practice and perceived employee performance and performance evaluation practices and perceived employee performance.

As far as the topic of the study is concerned, many studies have been conducted on particular topic in different sectors but no such study has been conducted in cement industry in Bangladesh. Now-a-days, the environment has become very competitive and they compete for quality of human resources. So this study will help the companies to know the perception of employees about HRM practices.

\section{Objectives of the Study}

- $\quad$ To find out the perception of employees about HRM practices.

- To find out the impact of HRM Practices (performance appraisal, training and development, career development, work life balance, compensation \& benefits and leadership practices) on employees performance of the cement industry in Bangladesh. 


\section{Conceptual Framework}

On the basis of the literature reviewed, it is clear that HRM practices affect the performance of the organization as well as performance of the employees. Now onwards the researcher has only talked about the impact of HRM practices on Employees performance which is the main theme of the study. A theoretical framework has been developed to understand the impact of HRM practices on Employees performance.

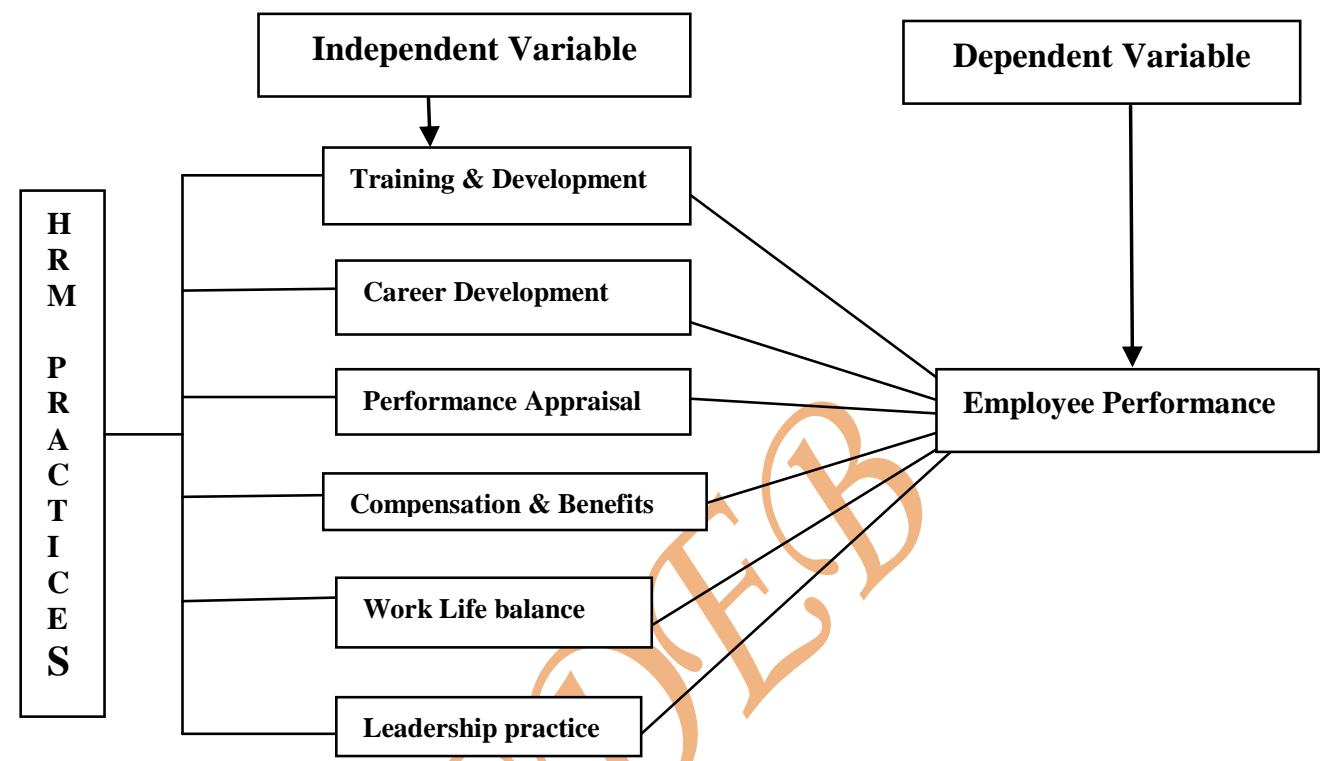

Figure 1: Schematic Diagram of the Conceptual Framework

The framework demonstrates that the employee's performance is influenced by HRM practices (Training \& Development, Performance appraisal, Career development, Compensation \& benefits, Work life balance and Leadership practices).

\section{Research Methodology}

The present paper is an empirical study based on exploratory research design followed by causal study to find out the impact of HRM practices on employees performance in cement industry of Bangladesh. So, the population of the study includes employees of the cement industry of Bangladesh. However, the sample was consisting of 160 employees of different cement companies located in Bangladesh. The researchers have used the convenience sampling technique for the selection of the respondents.

A self-administered questionnaire was applied to measure the impact of HRM practices on employee performance. At first, the questionnaires have been distributed to 200 employees of cement companies, out of that employees have returned 170 questionnaires. 10 questionnaires were rejected due to incompleteness. Finally, 160 questionnaires have been used for the study. The data were tabulated and analyzed with the help of regression analysis using SPSS software.

For measuring the impact of HRM practices on employee performance the independent variable includes various HRM practices like Training and development practices, 
Performance appraisal practices, Career development practices, Work life Balance Practices, Compensation and Benefits practices, Leadership Practices, and dependent variable includes Employees Performance.

The secondary data were collected from various documents, reports, articles, case studies, books, and internet and so on. The collected data were analyzed keeping in mind the objective of the study. The period of study is July 2012 to December 2012.

\section{FINDINGS}

\subsection{Reliability of the Data}

Before applying statistical tools, testing of the reliability of the scale is very much important as it shows the extent to which a scale produces consistent result if measurements were made repeatedly. This is done by determining the association in between scores obtained from different administrations of the scales. If the association is high, the scale yields consistent results, thus it is reliable. Cronbach's alpha is the most widely used method. It may be mentioned that its value varies from 0 to 1 but the satisfactory value is required to be more than 0.6 for the scale to be reliable (Malhotra, 2002; Cronbach, 1951). In the present study, we, therefore, used Cronbach's alpha scale as a measure of reliability.

Table 1: Reliability Statistics

\begin{tabular}{|l|l|l|}
\hline Questionnaire & Items & Cronbach's Alpha \\
\hline Performance Appraisal & 04 & .891 \\
\hline Training \& Development & 05 & .774 \\
\hline Career Development & 06 & .827 \\
\hline Compensation \& Benefits & 05 & .736 \\
\hline Work Life balance & 06 & .799 \\
\hline Leadership Practices & 04 & .825 \\
\hline Employee performance & 05 & .901 \\
\hline
\end{tabular}

Source: Primary

Table 1 shows the Cronbach's Alpha for HRM practices and EP questionnaire. The scores suggest that internal consistency of the questionnaire is satisfactory.

\subsection{Regression Analysis}

To find out the impact of HRM practices on Employees performance (EP) a regression analysis has been used and the results have been presented in table $2 \& 3$.

Table 2: Model summary

\begin{tabular}{|l|l|l|l|l|l|}
\hline $\mathrm{R}$ & $\mathrm{R} 2$ & Adjusted R2 & Std. error of the estimate & F- Value & Significance \\
\hline .701 & .487 & .453 & .519 & 13.22 & .000 \\
\hline
\end{tabular}

Source: Primary

The table 2 shows that the value of adjusted R2 is 0.453 which means that $45.30 \%$ of variance in employee performance is explained by the six independent variables and $55.70 \%$ of the fraction of the variation in the dependent variable is unexplained. This is probably due to the fact that the number of variables used in the analysis was not sufficient enough to deliver a better value of R-Square. There are many other factors such as internal conflict, personality, work environment, internal communication etc. that influence employee performance. The $f$ value is 
13.22 and the level of significance is 0.000 which means that there is a significant impact of HRM practices on employee performance it is supported by the findings of the study conducted by Ichniowski et al., (1995). In their study they found that complementary HR practice system effects workers performance.

The strengths of impact that each of the independent variable had on the dependent variable. i.e. employee performance was determined by the use of multiple regression coefficients of the independent variables. The impact of each independent variable is shown in Table 3.

Table3: Impact of the Individual Variables of HRM Practices on employee performance

\begin{tabular}{|l|l|l|l|l|}
\hline Variable & Std. error & Standard beta & $\mathbf{t}$ & Significance \\
\hline Performance Appraisal & .117 & 0.102 & 0.896 & 0.378 \\
Training \& Development & .130 & .297 & 2.891 & 0.005 \\
Career Development & .088 & .373 & 3.493 & 0.001 \\
Compensation \& Benefits & .119 & .112 & .952 & 0.346 \\
Work Life balance & .078 & -.037 & -.388 & 0.700 \\
Leadership Practices & .166 & .202 & 1.492 & 0.135 \\
\hline
\end{tabular}

Source: Primary

From the analytical table 3 it is exposed that all the measures of HRM practices have a positive impact on employee performance excepting work life balance. Training and development and career development have a significant positive impact on employee performance. On the other hand performance appraisal, leadership practices, and compensation \& benefits do not have significant impact on employee performance.

Training and development facilitates the employees to learn the new skills and competencies so that they can perform well on their job. The results of the study have shown the significant impact of T \& D on employee's performance with standard beta (0.297) and it is in line with the results of the study conducted by Marwat et al., (2009) in which they have found the highest correlation between Training and employee's performance. In present situation employees give proper importance to their career and they want to work for such institution which provides better career development policy and the result of the study has shown that the career development has a significant impact on employee's performance with highest standard beta (0.373).

As shown in table 3, the performance appraisal practices do not have significant impact on employee's performance and it is also confirmed by the findings of the study conducted by Shahzad et al., (2008) in which they have found that performance evaluations practices are not significantly correlated with perceived employee performance. The result also shows that compensation and benefits have a positive impact on employee's performance of the cement industry in Bangladesh.

Finally, the findings indicate that work life balance do not have any impact on employee's performance. The reason may be that in cement companies the work is carried out in shifts and employees keep moving from one shift to another so they think differently from employers about work life balance and this is the dim where there is a need to conduct further research. Furthermore, supportive and participative leadership style can increase the performance of the employees but on the other hand autocratic style of leadership can decrease the performance of the employees but the results of the study have shown that the leadership practices do not have significant impact on the performance of the employees. 


\section{CONCLUSION}

The regression model suggests that 45.30 percent of the total variance in employee's performance is explained by these HRM practices which mean that these aggregate HRM practices affects the performance of the employees of the cement companies to a greater extent. Hence it is very clear that HRM practices play a very important role in improving the performance of the employees As far as the individual HRM practices are concerned the researchers have found that the HRM practices like career development \& training and development have a significant impact on employees performance but the other practices like performance appraisal, work life balance, leadership practices and compensation \& benefits practices do not have a significant impact on employees performance.

Now this is very important for the cement companies to update the existing HRM practice and implement new innovative HRM practices. The survey should be conducted among the employees from time to time to know their satisfaction with the current practices and line managers should be involved in the process of designing or modifying the HRM practices. The new performance appraisal techniques like $360 \mathrm{O}$ should be implemented which will help the organization to collect the information about the employee's performance from variety of sources. Training and development should be strongly enforced in the culture of the organization. Organization should organize training programs for employees so that they can increase their skills and expertise. Training may be technical and behavioral. Such training programs should be conducted by experts. Organizations should encourage the culture of innovations. The techniques like mentoring, coaching should be used. Competency mapping should be done on regular basis. Career Development practices should be more strengthened in the organization because in present scenario the employees are more educated and are career conscious. Existing opportunities should be clearly communicated to the employees. The succession planning should be done on regular basis which will result in the availability of right talent for future vacancies at higher posts.

Compensation should be updated from time to time and it should be at par with the industry. Organization should have clear compensation policies and employees should be aware of the compensation policies. Competitive benefits such as medical, transportation, ESI (Employees State Insurance), PF (Provident Fund), LTC (Leave Travel Concession), rewards should be provided to the employees.

As far as the leadership is concerned it should be supportive and participative. Leaders should be available to the employees as and when required. Leaders should take initiative to motivate the employees and encourage them to come up with new ideas. Besides these the companies should provide additional facilities like vegetable shops, provision stores medical stores, transport facilities to the nearest city on regular basis so that family members should not depend on the employees for small things. They can purchase the routine items from these shops. Recreational centers, yoga facilities should also be provided so that they can refresh themselves after the work.

\section{REFERENCES}

[1] Baloch, B.Q, Ali, N., Kiani, S.T, \& Ahsan, A. (2010). Relationship between HR Practices and Perceived Employees' Performance of Bankers in NWFP, Pakistan: An Empirical Evidence. European Journal of Social Sciences - Vol. 18, No. 2.

[2] Barney, Jay. (1991). Firm Resources and Sustained Competitive Advantage. Journal of Management, Vol.17, pp.99-120. 
[3] Birdi, K., Clegg, C., Patterson, M., Robinson, A., Stride, B.C.,Wall, D.T., \& Wood, J.S.(2008). The Impact of Human Resource and Operational Management Practices on Company Productivity: A Longitudinal Study. Personnel Psychology, Vol. 61, pp. 467-501.

[4] Collins, C., Ericksen, J., Allen, M. (2005). Human Resource Management Practices and firm performance in small business. Cornell University/ Gevity Institute pp. 10.

[5] Cro n b a c h, L.J. (1951). Coefficient alpha and the internal structure of tests, Psychometrika, Vol.6, No.3, pp.297-334.

[6] Delaney, J.T., and Huselid, M.A. (1996). The impact of Human Resource management on Perceptions of Organizational Performance. The Academy of Management Journal, Vol. 39, No.4, 44. 949-969.

[7] Guest, D. (2002). Human Resource Management, Corporate Performance and Employee wellbeing: Building the worker into HRM. The Journal of Industrial Relations 44:3 335-358.

[8] Katou, A. A., and Budwar, P. S. (2007). The Effects of Human Resource Management Policies On Organizational Performance In Greek Manufacturing Firms. Thunderbird International Business Review, Vol.49, No.1, pp.1-35.

[9] Khan, A.M. (2010). Effects of Human Resource Management Practices on Organizational Performance - An Empirical Study of Oil and Gas Industry in Pakistan. European Journal of Economics, Finance and Administrative Sciences, Issue 24.

[10] Khatri, N. (1999). Emerging issues in Strategic HRM IN Singapore. International Journal of Manpower, Vol.20,No.8,pp.516-529.

[11] Khurram, S., Sajid, B., \& Ramay, M. I. (2008). Impact of HRM Practices on Perceived performance of University Teachers in Pakistan. International Review of Business Research Papers, Vol.4,No.2, pp.302-315.

[12] Lado .Augustine, A., and Mary, C.W. (1994). Human Resource Systems and Sustained Competitive Advantages: A Competency Based Perspective. Academy of Management Review, Vol.19, pp 699-727.

[13] Malhotra, N.K. (2002). Marketing research: an applied orientation (3 ${ }^{\text {rd }}$ ed.). New Delhi, India: Pearson Education Asia.

[14] Marwat, A.Z., Qureshi, M.T., \& Ramay, M.I. (2009). Impact of Human Resource Management (HRM) Practices on Employees Performance: A Case of Pakistani Telecom Sector. Unpublished Paper.

[15] Practices on Productivity. National Bureau of Economic Research Working Paper no 5333.

[16] Rundle, S.J.(1997). Flexibility, adaptiveness and responsiveness (FAR-ness) as the key success factors in market entry in the south east Asian growth wedge. PhD thesis, Department of Management, Monash University,Victoria.

[17] Shahzad, K., Bashir, S., \& Ramay, M. (2008). Impact of HR Practices on Perceived Performance of University Teachers in Pakistan. International Review of Business Research Papers, Vol. 4 No.2 March 2008 Pp.302-315.

[18] Singh, K. (2004). Impact of HR Practices on Perceived Firm Performance in India. Asia Pacific Journal of Human Resources, Vol. 42, No.3, pp.301-317.

[19] Tzafrir, S. S. (2006). A Universalistic Perspective for Explaining the Relationship between HRM Practices and Firm Performance At Different Points In Time. Journal of Managerial Psychology, Vol. 21, No.2, pp. 109-130.

[20] Wright, P. M., Garden, T. M., and Moynihan, L. M. (2003). The impact of HR practices on the performance of business units. Human Resource Management Journal, 13(3), 21-36. 